\title{
Effect of Plant Ash on Nutrient Quality and Antioxidant Activity of African Yam Bean Seed Porridge in Relation to Cooking Time
}

\author{
Anthony N. Ukom*, Faith C. Egejuru, \\ Philippa C. Ojimelukwe, Ugwuona U. Fabian \\ Department of Food Science and Technology, College of Applied Food Science and Tourism, Michael Okpara University of \\ Agriculture, Umudike, Nigeria \\ Email: *tony2008gospel@gmail.com
}

How to cite this paper: Ukom, A.N., Egejuru, F.C., Ojimelukwe, P.C. and Fabian, U.U. (2020) Effect of Plant Ash on Nutrient Quality and Antioxidant Activity of African Yam Bean Seed Porridge in Relation to Cooking Time. Food and Nutrition Sciences, 11, 591-602.

https://doi.org/10.4236/fns.2020.117042

Received: April 26, 2020

Accepted: July 6, 2020

Published: July 9, 2020

Copyright $\odot 2020$ by author(s) and Scientific Research Publishing Inc. This work is licensed under the Creative Commons Attribution International License (CC BY 4.0).

http://creativecommons.org/licenses/by/4.0/

(c) (i) Open Access

\begin{abstract}
The present study aimed to investigate the nutrient quality, antioxidant activity and sensory acceptability of hard-to-cook African yam bean (AYB) seeds cooked for $5 \mathrm{~h}$ (control) and for $2 \mathrm{~h}$ with plant ash. The plant ash were unripe plantain peel ash (UPA), corn cob ash (CCA) and UPA and CCA mixture. Standard methods of Association of Official Analytical Chemists (AOAC) were used for the proximate and mineral analysis, DPPH, ABTS and FRAP assays were used to investigate the antioxidant activity. A completely randomized design with one way analysis of variance (ANOVA) was used for data analysis. The results showed that cooking of AYB seeds for $2 \mathrm{~h}$ with $8 \mathrm{~g} / 100 \mathrm{~mL}$ plant ash solution improved the nutrient contents, antioxidant activity and sensory scores of the porridge. Higher values of proteins, ash and energy were obtained in $8 \mathrm{~g} / 100 \mathrm{~mL}$ UPA/CCA and in $8 \mathrm{~g} / 100 \mathrm{~mL}$ CCA additives. However, moisture, fat and fibre contents were not affected by plant ash additives and were higher in $5 \mathrm{~h}$ cooked porridge. Cooking with $8 \mathrm{~g} / 100 \mathrm{~mL}$ plant ash solution for $2 \mathrm{~h}$ significantly increased mineral elements in the porridge. Phenolic compounds (total polyphenols and flavonoids), and antioxidant activity (DPPH, ABTS and FRAP) showed higher values with plant ash additives. This study reveals that addition of plant ash did not only reduce the cooking time of AYB seed by $60 \%$, but also improved the nutrient quality, antioxidant activity and sensory acceptability.
\end{abstract}

\section{Keywords}

African Yam Bean, Plant Ash Porridge, Cooking Time, Nutrient Quality, Antioxidant Activity, Sensory Acceptability 


\section{Introduction}

African yam bean (AYB) (Sphenostylis stenocarpa) is an herbaceous leguminous plant with increasing nutritional interest in Nigeria and West African countries. As an important diet in West African countries, it complements the lack of proteins from cereals, roots and tubers. The amino acid profile of AYB seed is comparable to other legumes like cowpea, soybean and pigeon pea [1]. It is also rich in minerals and fiber [2]. However, utilization of AYB seed is limited due to the hard-to-cook (HTC) phenomenon arising from high temperature and relative humidity during storage [3], even up to nine months. This results in long cooking time and high energy expenditure, sometimes, overnight by the local people. Secondly, AYB seed contains some anti-nutritional factors and oligosaccharides which can provoke flatulence and chronic health effects.

Several authors have described the HTC phenomenon to changes occurring in the legume hull, cell wall and cotyledon in relation to legume hardening during storage [3] [4]. Others have linked phenolic compounds to hard-to-cook (HTC) phenomenon in legumes [5] [6].

To reduce the long cooking time and save energy and money, HTC legumes may be cooked using different salt solutions [7]. Trona, known by various names, for example, Akanwu in Igbo language of Nigeria is an alkaline salt that has been used by the locals in West Africa to tenderize or soften AYB seed hull and degrade phenolic compounds, thus reducing cooking time of AYB seed. Due to the purgative effect of trona to many users, plant ash sources have been discovered for use as alternatives tenderizer. Plant ash is obtained after complete incineration of some plant materials. Such materials include dried unripe plantain peel, corn cob, palm bunch and palm inflorescence [8] [9]. Legumes are potential sources of antioxidant compounds. The predominant antioxidant compounds in most legumes are flavonoids, tannins and phenolic acid, and according to Lin and Lai (2006), dark coat seeds possess high amount of phenolic compounds and antioxidant activity. The aim of this research was to determine the effect of solutions of unripe plantain ash (UPA) and corn cob ash (CCA) on the nutrient quality, antioxidant activity and sensory acceptability of African yam bean seed (AYB) porridge in relation to cooking time.

\section{Materials and Methods}

\section{Sources of raw materials}

African yam bean (AYB) seed (Sphenostylis stenocarpa) and corn cobs were purchased from Ubani market in Umuahia Metropolis of Abia state, Nigeria. Unripe plantain peel was obtained from Umuariga, Umudike, Ikwuano Local Government Area, Abia state.

\section{Sample Preparation}

Production of alkaline plant ash

The unripe plantain peel and corn cob ash were produced according the method of Abubakar et al. [10]. Matured unripe plantain peel was washed in water 
and allowed to dry in the sun for $21 \mathrm{~h}$. It was incinerated completely to ash on a flat concrete surface. The ash was transferred to a crucible and allowed to cool and then packaged in an air tight container. Corn cobs were sorted to remove unwanted parts. Thereafter, it was sun dried for $24 \mathrm{~h}$ and incinerated until only ash was obtained. Thereafter, the corn cob ash was allowed to cool and was packaged in an air tight container.

\section{Preparation of African yam bean (AYB) porridge}

Brown colored AYB seeds were sorted to remove sand, stone and dirt. The bean seeds were weighed and divided into 4 portions of $1.5 \mathrm{~kg}$ each. The first portion was cooked for $5 \mathrm{~h}$ without plant ash (control) according to method of Ukom et al. [11]. The second portion was cooked with $8 \mathrm{~g} / 100 \mathrm{~mL}$ un-ripened plantain ash (UPA) until it was fully done in $2 \mathrm{~h}$. The third portion was cooked with $8 \mathrm{~g} / 100 \mathrm{~mL}$ corn cobs ash (CCA) until it was fully done in $2 \mathrm{~h}$ and fourth portion was cooked with the mixture of $4 \mathrm{~g}: 4 \mathrm{~g} / 100 \mathrm{~mL}$ (UPA: CCA) until it was fully done in $2 \mathrm{~h}$. Each portion was first parboiled for 15 min with $2.5 \mathrm{~L}$ of potable water. The cooking water was drained off and the seeds hand washed with clean water. This was followed by continuous boiling with $3 \mathrm{~L}$ of water until the seeds softened in about $90 \mathrm{~min}$. Then other ingredients (pepper, palm oil, salt) were added and it further boiled for additional $15 \mathrm{~min}$. Four cooking stoves were used to achieve the cooking process.

\section{Determination of cooking time}

The method described by William et al. [12] was used to measure the cooking time. Cooking timing of $1.5 \mathrm{~kg}$ of AYB seeds commenced when the cooking water began to boil at $100^{\circ} \mathrm{C}$. After boiling for $15 \mathrm{~min}$, two to three seeds were taken with spatula to determine the degree of softening by compression of the seed in between two fingers. This process was continued until the seeds were fully softened with no gritty or grainy feeling in between two fingers. Thereafter, cooking time was recorded.

\section{Analysis and reagents}

The proximate, mineral and sensory analysis was done in Food Chemistry laboratory, Department of Food Science and Technology, Michael Okpara University of Agriculture, Umudike while the antioxidant activity analysis was done in Biochemistry laboratory, National Root Crops Research Institute, Umudike. All the reagents were of analytical grade.

\section{Proximate and mineral analysis}

The proximate composition of the AYB porridge was determined according to the AOAC method for nutrient analysis [13]. Moisture content was determined with $5 \mathrm{~g}$ of porridge by the Hot air oven (DHG9053A, England) method at $105^{\circ} \mathrm{C}$ for $4 \mathrm{~h}$ until a constant weight was obtained. Ash content was determined with $5 \mathrm{~g}$ of porridge by the dry ash method in a Muffle furnace (SX2-2.5-12NP, China) at $550^{\circ} \mathrm{C}$ by incineration for $4 \mathrm{~h}$, or until gray ash was obtained. Percentage protein content was determined with $2 \mathrm{~g}$ of porridge in three stages: digestion, distillation and titration by the Kjeldahl method (\%protein = \%nitrogen con- 
tent multiplied by 6.25). Two (2) $\mathrm{g}$ of porridge was used to determine the fat content by continuous petroleum ether extraction in Soxhlet apparatus with 200 $\mathrm{mL}$ of petroleum ether (boiling point $40^{\circ} \mathrm{C}-60^{\circ} \mathrm{C}$ ). Crude fiber was estimated by the gravimetric method, while carbohydrate content was calculated by difference. Carbohydrate content $=100-[$ moisture $(\%)+$ crude protein $(\%)+$ total fat (\%) + crude fiber (\%) + total ash (\%)].

Iron was determined by the method of James [14]. Calcium was determined by EDTA Versanate complexometric method of James [14]. Potassium was determined by a serial dilution of $\mathrm{K}$ solution of $0,2,4,6,8$ and $10 \mathrm{ppm}$ by flame photometry [15].

\section{Antioxidant activity}

Total polyphenol was determined by the method described by Jagadish et al. [16] with slight modification. Half (0.5) $\mathrm{mL}$ of AYB porridge methanolic extract was diluted with $10 \mathrm{~mL}$ of distilled water and $2.5 \mathrm{~mL}$ of $0.2 \mathrm{~N}$ Folin-Ciocalteu phenol reagent added to it in a $25 \mathrm{~mL}$ volumetric flask. After $5 \mathrm{~min}, 2 \mathrm{~mL}$ of $2 \%$ $\mathrm{Na}_{2} \mathrm{CO}_{3}$ solution was added and the mixture was made up to $25 \mathrm{~mL}$ volume with distilled water and allowed to stand for $90 \mathrm{~min}$. The absorbance was measured at $780 \mathrm{~nm}$ versus the prepared blank. Gallic acid was used as standard for the calibration curve. Total polyphenol content was calculated as mg Gallic acid equivalent per gram fresh weight of sample. Flavonoids content was estimated by $\mathrm{AlCl}_{3}$ method described by Jagadish et al. [16]. One and half (1.5) $\mathrm{mL}$ of the porridge extract was added to $5 \mathrm{~mL}$ of distilled water and $0.3 \mathrm{~mL}$ of $5 \% \mathrm{NaNO}_{2}$ in a $10 \mathrm{~mL}$ volumetric flask. It was properly mixed and after $5 \mathrm{~min}, 1.5 \mathrm{ml}$ of $2 \%$ methanolic $\mathrm{AlCl}_{3}$ solution was added and rested for $5 \mathrm{~min}$, then $2 \mathrm{~mL}$ of $1 \mathrm{~mol}$ $\mathrm{dm}^{-3} \mathrm{NaOH}$ was added. The volume was made up to $10 \mathrm{~mL}$ with distilled water, shaken vigorously for $5 \mathrm{~min}$ and incubated for $10 \mathrm{~min}$. The absorbance was read at $367 \mathrm{~nm}$ against the reagent blank. Flavonoid content was calculated using a standard calibration curve prepared from quercetin. The flavonoid content was expressed as mg quercetin per gram of fresh extract. $\mathrm{ABTS}^{+}$was prepared by adding solid manganese dioxide ( $80 \mathrm{mg}$ ) to a $5 \mathrm{mM}$ aqueous stock solution of ABTS (20 mL of $75 \mathrm{mM} \mathrm{Na} / \mathrm{K}$ buffer at $\mathrm{pH}$ 7) according to the method of Seeram et al. [17]. AYB porridge extract was diluted appropriately in $\mathrm{Na} / \mathrm{K}$ buffer pH 7 and mixed with $200 \mu \mathrm{L}$ of ABTS. ${ }^{+}$radical cation solution. The absorbance was read at $750 \mathrm{~nm}$ after $5 \mathrm{~min}$ in spectrophotometer (Jenway digital, England). ABTS values were calculated from Trolox standard curve and expressed as Trolox Equivalents in $\mu \mathrm{M}$. The DPPH radical scavenging activity of the porridge was determined by the method described by Manzocco et al. [18]. The porridge extract $(0.2 \mathrm{~mL})$ was diluted with $10 \mathrm{~mL}$ methanol and $2 \mathrm{~mL}$ DPPH solution $(0.5$ $\mathrm{mM}$ ) was added to it. After $30 \mathrm{~min}$, the absorbance was read at $517 \mathrm{~nm}$. The percentage of the DPPH radical scavenging activity was calculated using the equation given below. $\%$ Inhibition of DPPH radical $=\left(A_{O}-A_{S}\right) / A_{O} \times 100$; Where $A_{O}=$ absorbance of the control reaction containing all reagent except test sample, $A_{S}=$ absorbance of the porridge extract. The FRAP antioxidant assay was 
measured by the method developed by [19]. Three (3) mL of FRAP reagent was mixed with $100 \mu \mathrm{L}$ of diluted porridge extract. The absorbance at $593 \mathrm{~nm}$ was read after $30 \mathrm{~min}$ incubation at $37^{\circ} \mathrm{C}$. FRAP values was obtained by comparing the absorption change in the porridge extract with those obtained from increasing concentrations of $\mathrm{Fe}^{3+}$ and was expressed as $\mu \mathrm{M}$ of $\mathrm{Fe}^{2+}$ equivalents per $\mathrm{kg}$.

\section{Sensory evaluation of AYB porridge}

A nine-point hedonic scale was used to evaluate the sensory scores of the AYB porridge as affected by plant ash additive and cooking time. The rankings were 9 = like extremely, $8=$ like very much, $7=$ like moderately, $6=$ like slightly, $5=$ neither like nor dislike, $4=$ dislike slightly, 3 = dislike moderately, $2=$ dislike very much, and $1=$ dislike extremely [20]. An untrained panelists $(\mathrm{n}=30)$, mainly students, aged between 17 - 25 years were used. The AYB porridge was coded and served to 6 of the panelists in a randomized order in ceramic bowls to evaluate for colour, mouthfeel, taste, texture, and general acceptability. Each judge was offered sachet water to rinse the palate.

\section{Statistical analysis}

All experiments in this study are reported as mean of duplicate analysis in a completely randomized design (CRD) using the statistical package for Social Science (SPSS) version 18.0. Results were presented as means \pm standard deviations. One way analysis of variance (ANOVA) was used. Comparison of the means and differences between the means were separated using Duncan multiple range test at $95 \%$ confidence level $(\mathrm{p}<0.05)$.

\section{Results and Discussion}

\section{Effect of UPA and CCA additives in relation to cooking time on AYB seed porridge}

There was substantial decrease in cooking time of AYB seeds as a result of plant ash additives. Changes in hardness of AYB seed during cooking as measured by compression between two fingers were noticeable. Ojimelukwe [21] and Mubaiwa et al. [22] have shown that the lesser the compression, the softer the seeds of Bambara groundnut cooked in alkaline salt. The effect of alkaline plant ash (UPA, CCA) on cooking of AYB seeds and the percentage reduction in cooking time, in comparison with traditional (control) cooking in $5 \mathrm{~h}$ was $60 \%$. Plant ash, UPA $(8 \mathrm{~g} / 100 \mathrm{~mL})$, CCA $(8 \mathrm{~g} / 100 \mathrm{~mL})$ and UPA/CCA $(8 \mathrm{~g} / 100 \mathrm{~mL})$ had a cooking time of $2 \mathrm{~h}$. Using alkaline salt of $0.5 \mathrm{~g} / 100 \mathrm{~mL}$ gowa and $0.5 \mathrm{~g} / 100 \mathrm{~mL}$ $\mathrm{NaHCO}_{3}$, Mubaiwa et al. [22] found a decrease of 20\% and 13\% cooking time for red Bambara groundnut cooked for $120 \mathrm{~min}$ and $130 \mathrm{~min}$. It has been reported that the structural changes in the breakdown of middle lamellae, solubilization of pectin and proteins, breakdown of phenolic compounds that are linked to hard-to-cook legumes and water absorption caused by alkaline salt additives are other reasons for softening, time and energy reduction in cooking of legumes [22]. AYB seeds were cooked first for 15 min with $1.5 \mathrm{~L}$ of water which was drained off so as to reduce associated astringency and flatulence factors inherent 
in cooked AYB seed before final cooking and addition of $8 \mathrm{~g} / 100 \mathrm{~mL}$ plant ash solutions. AYB seed porridge was of brown colour, an indication that tannins solubilized by ash additives may have leached into the cooked porridge, an inference also made by [22], especially in brown or dark coated leguminous seeds [23].

Effect of plant ash on the proximate composition of AYB seed porridge in relation to cooking time

The effect of different plant ash, UPA and CCA on the proximate composition of African yam bean (AYB) porridge in relation to cooking time is shown in Table 1 . Plant ash additives significantly $(\mathrm{p}<0.05)$ increased the protein, ash and energy contents but not the moisture, fat and fibre which were higher in the control porridge. These results show that cooking of AYB porridge for $2 \mathrm{~h}$ with ash additive was considerably effective. The moisture content ranged from $32.57 \%$ in porridge cooked for $2 \mathrm{~h}$ with $8 \mathrm{~g} / 100 \mathrm{~mL}$ CCA to $34.73 \%$ in $5 \mathrm{~h}$ cooked porridge (control). The indication was that the powdered ash solution will have effect in binding the free moisture in the porridge, thus reducing the moisture content.

Protein is a major constituent of AYB seed that places the meals on high demand particularly among the low income population. Its protein content ranged from $22.58 \%$ to $24.02 \%$. Cooking with plant ash mixture UPA/CCA $(8 \mathrm{~g} / 100 \mathrm{~mL})$ for $2 \mathrm{~h}$ gave the highest value (24.02\%). These results indicate the effect of plant ash additive on protein availability in AYB porridge. Although ash is an inorganic substance, it enhanced the solubilization and release of free amino nitrogen in AYB seeds to potentially increase the protein content of the porridge. Baiyeri et al. [24] previously reported the protein values of $21.84 \%$ to $23.40 \%$ in AYB seed, as opposed to $26.35 \%, 27.87 \%$ and $31.80 \%$ reported by Ukom et al. [11] on AYB porridge after fermenting the seeds for 24,48 and $72 \mathrm{~h}$, respectively. The fat and fibre contents of AYB porridge was not affected by ash additives and were highest in $5 \mathrm{~h}$ cooked porridge (Table 1 ). AYB seeds were not de-hulled upon cooking, and the fat and fibre contents were not affected since there was no plant ash addition. The ash content ranged from $2.67 \%$ to $4.02 \%$ and increased linearly in descending order: 4.02\% (CCA/UPA) > 3.97\% (CCA) > $3.73 \%$ (UPA) $>2.67 \%$ (control). Plant ash contents have corresponding mineral

Table 1. Effect of plant ash on the proximate composition of AYB seed porridge in relation to cooking time.

\begin{tabular}{cccccccc}
\hline $\begin{array}{c}\text { Samples } \\
\text { Code }\end{array}$ & $\begin{array}{c}\text { Moisture } \\
\text { content (\%) }\end{array}$ & $\begin{array}{c}\text { Crude protein } \\
(\%)\end{array}$ & Fat (\%) & Crude fibre (\%) & Ash (\%) & $\begin{array}{c}\text { Carbohydrate } \\
(\%)\end{array}$ & $\begin{array}{c}\text { Energy value } \\
(\text { Kcal) }\end{array}$ \\
\hline 501 & $34.73^{\mathrm{a}} \pm 0.02$ & $22.66^{\mathrm{c}} \pm 0.01$ & $4.82^{\mathrm{a}} \pm 0.01$ & $7.88^{\mathrm{a}} \pm 0.02$ & $2.67^{\mathrm{c}} \pm 0.01$ & $27.25^{\mathrm{c}} \pm 0.06$ & $243.02^{\mathrm{d}} \pm 0.16$ \\
502 & $32.85^{\mathrm{c}} \pm 0.02$ & $22.58^{\mathrm{d}} \pm 0.01$ & $4.44^{\mathrm{d}} \pm 0.01$ & $7.57^{\mathrm{b}} \pm 0.01$ & $3.73^{\mathrm{b}} \pm 0.04$ & $28.88^{\mathrm{a}} \pm 0.01$ & $245.80^{\mathrm{c}} \pm 0.13$ \\
503 & $32.57^{\mathrm{d}} \pm 0.02$ & $23.91^{\mathrm{b}} \pm 0.01$ & $4.54^{\mathrm{c}} \pm 0.01$ & $7.47^{\mathrm{c}} \pm 0.02$ & $3.97^{\mathrm{a}} \pm 0.01$ & $27.55^{\mathrm{b}} \pm 0.00$ & $246.70^{\mathrm{b}} \pm 0.18$ \\
504 & $33.20^{\mathrm{b}} \pm 0.01$ & $24.02^{\mathrm{a}} \pm 0.03$ & $4.60^{\mathrm{b}} \pm 0.01$ & $7.51^{\mathrm{c}} \pm 0.01$ & $4.02^{\mathrm{a}} \pm 0.03$ & $26.66^{\mathrm{d}} \pm 0.06$ & $248.04^{\mathrm{a}} \pm 0.07$ \\
\hline
\end{tabular}

Values are means \pm standard deviation of duplicate determination. Mean values in the same column with different superscript are significantly different ( $\mathrm{p}<$ 0.05). Keys: 501 (AYB porridge cooked for $5 \mathrm{~h}$ [Control]), 502 (AYB porridge cooked for $2 \mathrm{~h}$ with $8 \mathrm{~g} / 100 \mathrm{~mL}$ UPA), 503 (AYB porridge cooked for $2 \mathrm{~h}$ with $8 \mathrm{~g} / 100 \mathrm{~mL} \mathrm{CCA}$ ) and 504 (AYB porridge cooked for $2 \mathrm{~h}$ with $8 \mathrm{~g} / 100 \mathrm{~mL}$ UPA/CCA). 
nutrition in foods, except for being bound and non-available by anti-nutrients. Das et al. [25] has opined that foods possessing ash content of $3 \%$ and above are ideal for mineral nutrition. Therefore, alkaline plant ash of vegetable origin may be used as a mineral supplement in cases of established mineral deficiency. As it is the case, AYB seeds as legumes have low carbohydrate and energy contents. In comparison to cereals, roots and tubers with high carbohydrate content and energy value, AYB seeds can be used as food for diabetics and convalescence. These results clearly demonstrate that plant ash additives, being alkaline, can degrade and solubilize some hard-to-cook factors and phenolic compounds in AYB seeds [3]. Plant ash used in this study reduced the cooking time and fuel by $60 \%$ and positively improved the availability of some nutrient contents.

Effect of plant ash on the mineral content of AYB seed porridge in relation to cooking time

Table 2 shows the mineral contents of AYB porridge cooked with plant ash additives in relation to cooking time. Plant ash additives significantly $(p<0.05)$ increased the mineral nutrients when compared to the control. Porridge cooked for $2 \mathrm{~h}$ with the mixture of UPA/CCA had the highest value of $\mathrm{Ca}$ (215.43 $\mathrm{mg} / 100 \mathrm{~g}), \mathrm{K}(169.02 \mathrm{mg} / 100 \mathrm{~g}), \mathrm{P}(32.21 \mathrm{mg} / 100 \mathrm{~g})$ and $\mathrm{Fe}(14.07 \mathrm{mg} / 100 \mathrm{~g})$, respectively. These results show the richness of plant ash as a mineral source [9], and increased the $\mathrm{Fe}, \mathrm{K}, \mathrm{Ca}$ and $\mathrm{P}$ contents by $28 \%, 16.5 \%, 3.1 \%$ and $2.6 \%$ when compared to the control. The mineral contents of UPA as previously reported by [9] were for $\mathrm{Ca}(295.16 \mathrm{mg} / 100 \mathrm{~g}), \mathrm{K}(528.58 \mathrm{mg} / 100 \mathrm{~g}), \mathrm{Fe}(7.14 \mathrm{mg} / \mathrm{kg})$ and $\mathrm{P}(196.02 \mathrm{mg} / 100 \mathrm{~g})$, and in CCA the following mineral contents were reported for Fe (26.18 mg/100g), P (527.33 mg/100g), K (375.25 mg/100g), Mg (21.92 $\mathrm{mg} / 100 \mathrm{~g})$ and $\mathrm{Ca}(17.19 \mathrm{mg} / 100 \mathrm{~g})$ [10]. Mineral nutrition is important in maintaining the health status of the individual. These mineral salts, $\mathrm{Ca}$ and $\mathrm{K}$ are important regulars of the acid-base balance of the body, Fe works together with $\mathrm{Zn}$ mineral to improve the immune defense system, while $\mathrm{Ca}$ and $\mathrm{P}$ are important in bone mass development especially in children [26]. The mineral nutrients from AYB porridge can contribute substantially to mineral nutrition of the consumers.

Table 2. Effect of plant ash on mineral composition of AYB porridge in relation to cooking time.

\begin{tabular}{ccccc}
\hline Porridge & $\begin{array}{c}\text { Potassium } \\
(\mathrm{mg} / \mathbf{1 0 0 g})\end{array}$ & $\begin{array}{c}\text { Iron } \\
(\mathrm{mg} / \mathbf{1 0 0 g})\end{array}$ & $\begin{array}{c}\text { Calcium } \\
(\mathrm{mg} / 100 \mathrm{~g})\end{array}$ & $\begin{array}{c}\text { Phosphorus } \\
(\mathrm{mg} / \mathbf{1 0 0 g})\end{array}$ \\
\hline 501 & $141.12^{\mathrm{d}} \pm 0.02$ & $10.15^{\mathrm{d}} \pm 0.02$ & $208.76^{\mathrm{d}} \pm 0.03$ & $31.37^{\mathrm{d}} \pm 0.03$ \\
502 & $164.34^{\mathrm{c}} \pm 0.02$ & $12.96^{\mathrm{c}} \pm 0.04$ & $208.94^{\mathrm{c}} \pm 0.02$ & $31.67^{\mathrm{c}} \pm 0.01$ \\
503 & $167.55^{\mathrm{b}} \pm 0.03$ & $13.78^{\mathrm{b}} \pm 0.02$ & $209.95^{\mathrm{b}} \pm 0.01$ & $31.75^{\mathrm{b}} \pm 0.02$ \\
504 & $169.02^{\mathrm{a}} \pm 0.02$ & $14.07^{\mathrm{a}} \pm 0.03$ & $215.43^{\mathrm{a}} \pm 0.04$ & $32.21^{\mathrm{a}} \pm 0.00$ \\
\hline
\end{tabular}

Values are means standard deviation of duplicate determination. Mean values in the same column with different superscript is significantly $(\mathrm{p}<0.05)$ different. Keys: 501 (AYB porridge cooked for $5 \mathrm{~h}$ without plant ash), 502 (AYB porridge cooked for $2 \mathrm{~h}$ with $8 \mathrm{~g}$ UPA), 503 (AYB porridge cooked for $2 \mathrm{~h}$ with $8 \mathrm{~g}$ CCA), 504 (AYB porridge cooked for $2 \mathrm{~h}$ with $4 \mathrm{~g}$ UPA and $4 \mathrm{~g}$ CCA). 
Effect of plant ash on antioxidant activity of AYB porridge in relation to cooking time

The effect of plant ash additives on antioxidant activity of AYB porridge in relation to cooking is shown in Table 3. Significant $(p<0.05)$ variations were observed in the polyphenol concentrations, with higher value in AYB porridge cooked for $2 \mathrm{~h}$ in $8 \mathrm{~g} / 100 \mathrm{~mL}$ UPA/CCA mixture. However, cooking for $2 \mathrm{~h}$ with $8 \mathrm{~g} / 100 \mathrm{~mL} \mathrm{CCA}$, or $8 \mathrm{~g} / 100 \mathrm{~mL}$ UPA obtained the higher flavonoids concentrations (47.90 and $47.88 \mathrm{mgCE} / 100 \mathrm{~g}$.

The hard-to-cook (HTC) phenomenon in legumes has been linked to high content of phenolic compounds in beans [6] [27]. To reduce the HTC phenomenon in relation to cooking time and fuel, plant ash was used to tenderize the AYB seed hulls resulting in higher phenolics from solubilized tannins into the porridge. Tannins can be degraded at $100^{\circ} \mathrm{C}$ (cooking temperature) and increase phenolic compounds [28]. Boiled raw dry mung bean seeds (Phaseolus aureus), and soaked and cooked legumes with sodium bicarbonate caused the reduction of tannins from $3.3 \mathrm{mg} / \mathrm{g}$ to $45.5 \%$ [29], and 66\% [30], and would increase the polyphenol content in the case of cooked porridge foods. Antioxidant activity assayed by DPPH, ABTS and FRAP showed significant increases, varying with plant ash additives in $2 \mathrm{~h}$ of cooking. The weakest strength was obtained from 5 $\mathrm{h}$ cooked porridge (control). For plant ash additives, the strongest value was obtained in UPA/CCA mixture for \%DPPH (30\%), ABTS (23.97 mgTE/100g), and FRAP (188.01 mgTE/100g). Different antioxidant assays were used in this study in order to determine the antioxidant activities of the phenolic compounds of AYB porridge cooked for $2 \mathrm{~h}$ with plant ash. These results indicate strong antioxidant activity in FRAP assay to chelate pro-oxidant metals and reduced $\mathrm{Fe}^{3+}$ to $\mathrm{Fe}^{2+}$ in the plant ash cooked porridge. The contribution of phenolic compounds to softening of HTC legumes was reported by del-Valle et al. [31]. They further stated that chelating and ion-exchange agents can affect the softening of soaked beans. In addition, cooking at $100^{\circ} \mathrm{C}$ may have effect on AYB seed matrix, and causing the release of bound phenolic compounds from the seed structure that influence total phenolic increase in leguminous seeds [32]. The concentrations

Table 3. Effect of plant ash on antioxidant activity of AYB seed porridge in relation to cooking time.

\begin{tabular}{cccccc}
\hline Porridge & \%DPPH & $\begin{array}{c}\text { FRAP } \\
(\mathrm{mgTE} / 100 \mathrm{~g})\end{array}$ & $\begin{array}{c}\text { Polyphenol } \\
(\mu \mathrm{molGAE} / 100 \mathrm{~g})\end{array}$ & $\begin{array}{c}\text { Flavonoid } \\
(\mathrm{CE} / 100 \mathrm{~g})\end{array}$ & $\begin{array}{c}\text { ABST } \\
(\mathrm{TE} / 100 \mathrm{~g})\end{array}$ \\
\hline 501 & $28.68^{\mathrm{d}} \pm 0.02$ & $87.57^{\mathrm{d}} \pm 0.01$ & $77.23^{\mathrm{c}} \pm 0.04$ & $47.67^{\mathrm{b}} \pm 0.02$ & $23.54^{\mathrm{c}} \pm 0.04$ \\
502 & $29.37^{\mathrm{c}} \pm 0.02$ & $87.88^{\mathrm{b}} \pm 0.02$ & $77.59^{\mathrm{b}} \pm 0.02$ & $47.88^{\mathrm{a}} \pm 0.02$ & $23.76^{\mathrm{b}} \pm 0.02$ \\
503 & $29.45^{\mathrm{b}} \pm 0.03$ & $87.82^{\mathrm{c}} \pm 0.03$ & $77.63^{\mathrm{b}} \pm 0.02$ & $47.90^{\mathrm{a}} \pm 0.02$ & $23.77^{\mathrm{b}} \pm 0.03$ \\
504 & $30.00^{\mathrm{a}} \pm 0.01$ & $88.01^{\mathrm{a}} \pm 0.01$ & $79.37^{\mathrm{a}} \pm 0.04$ & $47.10^{\mathrm{c}} \pm 0.01$ & $23.97^{\mathrm{a}} \pm 0.00$ \\
\hline
\end{tabular}

Values are means \pm standard deviation of duplicate determination. Mean values in the same column with different superscript are significantly different $(\mathrm{p}<0.05)$. Keys: 501 (AYB porridge cooked for $5 \mathrm{~h}$ [Control]), 502 (AYB porridge cooked for $2 \mathrm{~h}$ with $8 \mathrm{~g} / 100 \mathrm{~mL} \mathrm{UPA}$ ), 503 (AYB porridge cooked for $2 \mathrm{~h}$ with 8 $\mathrm{g} / 100 \mathrm{~mL} C C A$ ) and 504 (AYB porridge cooked for $2 \mathrm{~h}$ with $8 \mathrm{~g} / 100 \mathrm{~mL}$ UPA/CCA). 
Table 4. Effect of plant ash on sensory properties of AYB seed porridge in relation to cooking time.

\begin{tabular}{cccccc}
\hline Samples & Colour & Mouthfeel & Taste & Texture & General Acceptability \\
\hline 501 & $6.83^{\mathrm{c}} \pm 0.34$ & $6.71^{\mathrm{bc}} \pm 0.38$ & $6.71^{\mathrm{c}} \pm 0.32$ & $6.79^{\mathrm{b}} \pm 0.31$ & $7.29^{\mathrm{bc}} \pm 0.27$ \\
502 & $7.79^{\mathrm{a}} \pm 0.29$ & $7.46^{\mathrm{a}} \pm 0.22$ & $7.29^{\mathrm{a}} \pm 0.19$ & $7.29^{\mathrm{a}} \pm 0.20$ & $8.04^{\mathrm{a}} \pm 0.18$ \\
503 & $7.33^{\mathrm{b}} \pm 0.32$ & $6.75^{\mathrm{b}} \pm 0.31$ & $7.13^{\mathrm{b}} \pm 0.24$ & $6.63^{\mathrm{c}} \pm 0.29$ & $7.38^{\mathrm{b}} \pm 0.24$ \\
504 & $6.38^{\mathrm{d}} \pm 0.28$ & $6.25^{\mathrm{c}} \pm 0.25$ & $5.71^{\mathrm{d}} \pm 0.38$ & $5.21^{\mathrm{d}} \pm 0.41$ & $6.33^{\mathrm{d}} \pm 0.34$
\end{tabular}

Values are means \pm standard deviation of duplicate determination. Mean values in the same column with different superscript are significantly different ( $\mathrm{p}<0.05$ ). Key: 501 (AYB cooked for $5 \mathrm{~h}$ without plant ash), 502 (AYB cooked for $2 \mathrm{~h}$ with $8 \mathrm{~g} / 100 \mathrm{~mL}$ of UPA), 503 (AYB cooked for $2 \mathrm{~h}$ with $8 \mathrm{~g} / 100 \mathrm{~mL}$ of CCA), 504 (AYB cooked for 2 hours with blends of ratio $4 \mathrm{~g} / 100 \mathrm{~mL}$ UPA: $4 \mathrm{~g} / 100 \mathrm{~mL}$ CCA).

of phenolic compounds (Table 3 ) indicates the positive contribution of plant ash to antioxidant activity in AYB seed porridge.

Effect of plant ash on the sensory properties of AYB seed porridge in relation to cooking time

Table 4 shows the effect of plant ash on sensory properties of AYB seed porridge in relation to cooking time. Several traditional methods are used for processing of AYB seed to acceptable meals. The use of kanwa, (alkaline rock salt), $\mathrm{NaHCO}_{3}$ or some other salts to cook legume seeds in order to reduce the cooking time was reported by Uzogara et al. [7]. Akanwu (Igbo language) is also used to make sponge in abacha (shredded tapioca) snack, and today it is not acceptable by the generality of the people because of its organoleptic quality and health risk factors. This has resulted in an alternative alkaline salt like plant ash for this and other purposes. Variation in cooking time and plant ash additive significantly ( $\mathrm{p}$ $<0.05)$ affected the mean sensory scores. The sensory mean scores ranged from 5 (neither like nor dislike) to 8 (like very much). Preference was more for UPA additive, followed by CCA before the control. According to Dehghan-Shoar et al. [33], sensory scores of foods are a combination of the organoleptic properties like colour, aroma, taste and texture. In this study, colour, mouth-feel, taste, texture and general acceptability were highest in AYB porridge cook for $2 \mathrm{~h}$ with UPA. So the use of these plant ashes greatly affected their higher acceptability scores for colour, mouth-feel, taste and texture. The results imply that 8 $\mathrm{g} / 100 \mathrm{~mL}$ plant ash inclusion in cooking of $1.5 \mathrm{~kg}$ AYB porridge for $2 \mathrm{~h}$ can be used to replace the traditional method of AYB seeds cooked for $5 \mathrm{~h}$. Overall, alkaline salt used in this study decreased cooking time, increased nutritive value, improved sensory properties of HTC AYB seeds and reduced energy usage by $60 \%$ and household income.

\section{Conclusion}

The effect of plant ash on nutrient quality, antioxidant activity and sensory acceptability of AYB seed porridge in relation to cooking time was studied. The results showed that cooking of AYB seeds for $2 \mathrm{~h}$ with plant ash $(8 \mathrm{~g} / 100 \mathrm{~mL})$ significantly improved the nutrient and sensory qualities, especially the protein, 
ash, energy, and mineral contents. However, moisture, fat, fibre was higher in porridge cooked for $5 \mathrm{~h}$ without plant ash. Also AYB seed porridge cooked for 2 $\mathrm{h}$ with plant ash showed higher concentrations of DPPH, ABTS, FRAP, total polyphenol and flavonoids. It is established that cooking with plant ash caused a breakdown and solubilization of phenolic compounds in AYB seed hull and cotyledon resulting into higher antioxidant compounds in the porridge. Sensory evaluation revealed that AYB seeds cooked for $2 \mathrm{~h}$ with plant ash, especially UPA was more preferred in overall acceptability. Cooking of AYB seeds with plant ash for $2 \mathrm{~h}$ was able to handle the HTC problem.

\section{Conflicts of Interest}

The authors declare no conflicts of interest regarding the publication of this paper.

\section{References}

[1] Uguru, M.I. and Madukaife, S.O. (2001) Studies on the Variability in Agronomic and Nutritive Characteristics of African Yam Bean (Sphenostylis stenocarpa Hochst ex. A. Rich. Harms). Production and Research Journal, 6, 10-19.

[2] Fasoyiro, S.B., Ajibade, S.R., Omole, A.J., Adeniyan, O.N. and Farinde, E.O. (2006) Proximate, Mineral and Anti-Nutritional Factors of Some Under-Utilized Grain Legumes in Southwestern, Nigeria. Nutrition and Food Science, 36, 18-23. https://doi.org/10.1108/00346650610642151

[3] Afoakwa, E.O. and Sefa-Debeh, S. (2002) Changes in Cell Wall Constituents and Mechanical Properties during Post-Harvest Handling of Trifoliate Yam Dioscorea dumentorum (Kunth) Pax Tubers. Food Research International, 35, 429-434. https://doi.org/10.1016/S0963-9969(01)00137-5

[4] Shiga, T.M., Cordenunsi, B.R. and Lajolo, F.M. (2008) Effect of Cooking on NonPolysaccharides of Hard-to-Cook Beans. Carbohydrate Polymers, 76, 100-109. https://doi.org/10.1016/j.carbpol.2008.09.035

[5] Stanley, D.W. (1992) A Possible Role for Condensed Hard Tannins in Beans. Food Research International, 25, 187-192. https://doi.org/10.1016/0963-9969(92)90136-S

[6] Basu, S., Roberts, J.A., Azam-Ali, S.N. and Mayes, S. (2007) Bambara Groundnut. In: Kole, C., Ed., Genome Mapping and Molecular Breeding in Plant Pulses, Sugar and Tuber Crops, Vol. 3, Springer Verlag, Berlin Heidelberg, 161-173.

[7] Uzogara, S.G., Morton, I.D. and Daniel, J.W. (1990) Changes in Some Antinutrients of Cowpea (Vigna unguiculata) Processed with Kanwa Alkaline Salt. Plant Food for Human Nutrition, 40, 249-258. https://doi.org/10.1007/BF02193848

[8] Egbuonu, A.C.C. and Nzewi, D.C. (2014) Evaluation of Some Nutritional and Sensory Characteristics of Bread-Fruit Cooked with Various Food-Waste Ash Infusion. Research Journal of Medicinal Plant, 8, 277-282.

https://doi.org/10.3923/rjmp.2014.277.282

[9] Okwunodulu, I.N., Anthony, U.C. and Okwunodulu, F.U. (2018) Potential Mineral Exploration of Food Grade Ash from Dried Empty Palm Bunch, Palm Inflorescence and Unripe Plantain Peels: A Comparative Assessment. Nigerian Journal of Agriculture, Food and Environment, 14, 64-73. https://doi.org/10.9734/afsj/2019/v9i230008

[10] Abubakar, U.S., Yusuf, K.M., Saflyanu, I., Abdullahi, S., Saidu, S.R., Abdu, G.T. and 
Indee, A.M. (2016) Proximate and Mineral Composition of Corn Cob, Banana and Plantain Peels. International Journal of Food Science and Nutrition, 1, 25-27.

[11] Ukom, A.N., Ndudim, S. and Nwanagba, L.N. (2019) Effect of Fermentation Periods on the Nutrient Quality and Sensory Acceptability of African Yam Bean (Sphenostylis sterocarpa) Porridge. Nigerian Journal of Biotechnology, 36, 9-16. https://doi.org/10.4314/njb.v36i1.2

[12] Williams, P.C., Nakoul, H. and Singh, K.B. (1983) Relationship between Cooking Time and Some Physical Characteristics in Chickpeas (Cicer arietinum L.). Journal Science of Food and Agriculture, 34, 492-496. https://doi.org/10.1002/jsfa.2740340510

[13] AOAC Association of Official Analytical Chemists (2010) Official Methods of Analysis. 18th Edition, AOAC International, Rockville.

[14] James, C.S. (1995) Mineral Composition of Nonconventional Leafy Vegetables. Plant Food for Human Nutrition, 53, 29-36.

[15] Carpenter, C.E. and Hendricks, D.G. (2003) Mineral Analysis. In: Nielsen, S.S., Ed., Food Analysis, 3rd Edition, Springer Science and Business Media Publisher, New York, 195.

[16] Jagadish, L.K., Krishan, V.V., Shenbhagaraman, R. and Kaviyarasan, V. (2009) Comparative Study on the Antioxidant, Anticancer and Antimicrobial Property of Agaricus bisporus Imbach before and after Boiling. African Journal of Biotechnolo$g y$, 8, 654-661.

[17] Seeram, N.L., Adams, Y., Zhang, R., Lee, D., Sand, H., Scheuller and Heber, D. (2006) Blackberry, Black Raspberry, Blueberry. Cranberry, Red Raspberry and Strawberry Extract Inhibit Growth and Stimulate Apoptosis of Human Cancel Cell in Vitro. Journal of Agricultural and Food Chemistry, 54, 9329-9339. https://doi.org/10.1021/jf061750g

[18] Manzocco, L., Anese M. and Nicoli, M.C. (1998) Antioxidant Properties of Tea Extracts as Affected by Processing. LWT Food Science and Technology, 31, 694-698. https://doi.org/10.1006/fstl.1998.0491

[19] Benzie, I.F.F. and Strain, J.J. (1999) Ferric Reducing/Antioxidant Power Assay: Direct Measure of Total Antioxidant Activity of Biological Fluids and Modified Version for Stimultaneous Measurement of Total Antioxidant Power and Ascorbic Acid Concentration. In: Packer, L., Ed., Methods in Enzymology, Vol. 299, Academic Press, Orlando, 15-27. https://doi.org/10.1016/S0076-6879(99)99005-5

[20] Lawless, T.H. and Heymann, H. (2010) Sensory Evaluation of Foods. Principles and Practice. 2nd Edition, Springer, New York.

[21] Ojimelukwe, P.C. (1998) Cooking Characteristics of Four Cultivars of Bambara Groundnut Isolates. Journal of Food Biochemistry, 23, 109-117. https://doi.org/10.1111/j.1745-4514.1999.tb00008.x

[22] Mubaiwa, J., Fogliano, V., Chidewe, C. and Linnemann, A.R. (2019) Influence of Alkaline Salt Cooking on Solubilisation of Phenolic Compounds of Bambara Groundnut (Vigna subterranean (L) Verdc.) in Relation to Cooking Time Reduction. LMTFood Science and Technology, 107, 49-55. https://doi.org/10.1016/j.lwt.2019.02.067

[23] Lin, P.Y. and Lai, H.M. (2006) Bioactive Compounds in Legumes and Their Germinated Products. Journal of Agricultural and Food Chemistry, 62, 3807-3814. https://doi.org/10.1021/jf060002o

[24] Baiyeri, S.O., Uguru, M.M.I., Ogbonna, P.E., Samuel-Baiyeri, C.C.A., Okechukwu, R., Kumaga, F.K. and Amoatey, C. (2018) Evaluation of the Nutritional Composition of Some Selected African Yam Bean Accessions. Journal of Tropical Agricul- 
ture, Food, Environment and Extension, 17, 37-44.

https://doi.org/10.4314/as.v17i2.5

[25] Das, P., Devi, P. and Gogoi, M. (2009) Nutrient Composition of Some Regional Recipes of Assam, India. Ethno-Medicine, 3, 111-117.

https://doi.org/10.1080/09735070.2009.11886347

[26] Ukom, A.N., Adiegwu, E.C., Ojimelukwe, P.C. and Okwunodulu, I.N. (2019) Quality and Sensory Acceptability of Yellow Maize Ogi Porridge Enriched with OrangeFleshed Sweet Potato and African Yam Bean Seed Flours for Infants. Scientific African, 6, e00194. https://doi.org/10.1016/j.sciaf.2019.e00194

[27] Machado, C.M., Ferruzi, M.G. and Nielson, S.S. (2008) Impact of the Hard-to-Cook Phenomenon on Phenolic Antioxidants in Dry Beans (Phaseolus vulgaris). Journal of Agricultural and Food Chemistry, 56, 3102-3110.

https://doi.org/10.1021/jf072861y

[28] Cheng, Z., Su, L., Moore, J., Zhou, K., Luther, M., Yin, J. and Yu, L. (2006) Effect of Post-Harvest Treatment and Heat Stress on Availability of Wheat Antioxidants. Journal of Agricultural and Food Chemistry, 54, 5623-5629. https://doi.org/10.1021/jf060719b

[29] Mubarak, A.E. (2005) Nutritional Composition and Anti-Nutritional Factors of Mung Bean Seeds (Phaseolus aureus) as Affected by Some Traditional Process. Food Chemistry, 89, 489-495. https://doi.org/10.1016/j.foodchem.2004.01.007

[30] Huma, N., Anjum, M., Sehar, S., Khan, M.I. and Hussain, S. (2008) Effect of Soaking and Cooking on Nutritional Quality and Safety of Legumes. Nutrition and Food Science, 38, 570-577. https://doi.org/10.1108/00346650810920187

[31] del-Valle, J.M., Cottrel, T.J., Jackman, R.I. and Stanley, D.W. (1992) Hard-to-Cook Defects in Black Beans: The Contribution of Protein to Salt Soaking Effect. Food Research International, 25, 429-436. https://doi.org/10.1016/0963-9969(92)90167-4

[32] Fulcher, R.G. and Rooney Duke, T.K. (2002) Whole Grain Structure and Organization: Implications for Nutritionists and Processors. In: Marquart, L., Fulcher, R.G. and Slavin, J.L., Eds., Whole Grain Foods in Health and Disease, American Association of Cereal Chemists, St. Paul, 9-45.

[33] Dehghan-Shoar, Z., Hardacre, A.K. and Brenann, C.S. (2010) The Physicochemical Characteristics of Extruded Snacks Enriched with Tomato Lycopence. Food Chemistry, 123, 1117-1122. https://doi.org/10.1016/j.foodchem.2010.05.071 